\title{
Correction to: Molecular mechanisms mediating root hydrotropism: what we have observed since the rediscovery of hydrotropism
}

\author{
Yutaka Miyazawa $^{1}$ (D) Hideyuki Takahashi
}

Published online: 25 March 2020

(c) The Author(s) 2020

\section{Correction to: Journal of Plant Research (2020) 133:3-14 https://doi.org/10.1007/s10265-019-01153-3}

The article Molecular mechanisms mediating root hydrotropism: what we have observed since the rediscovery of hydrotropism, written by Yutaka Miyazawa and Hideyuki Takahashi, was originally published Online First without Open Access. After publication in volume 133, issue 1, pages 3-14 the author decided to opt for Open Choice and to make the article an Open Access publication. Therefore, the copyright of the article has been changed to $\odot$ The Author(s) 2020 and the article is forthwith distributed under the terms of the Creative Commons Attribution 4.0 International License (https://creativecommons.org/licenses/by/4.0/), which permits use, duplication, adaptation, distribution and reproduction in any medium or format, as long as you give appropriate credit to the original author(s) and the source, provide a link to the Creative Commons license, and indicate if changes were made.

The original article was updated.

Open Access This article is licensed under a Creative Commons Attribution 4.0 International License, which permits use, sharing, adaptation, distribution and reproduction in any medium or format, as long as you give appropriate credit to the original author(s) and the source, provide a link to the Creative Commons licence, and indicate if changes were made. The images or other third party material in this article are included in the article's Creative Commons licence, unless indicated otherwise in a credit line to the material. If material is not included in the article's Creative Commons licence and your intended use is not permitted by statutory regulation or exceeds the permitted use, you will

The original article can be found online at https://doi.org/10.1007/ s10265-019-01153-3.

Yutaka Miyazawa

miyazawa@sci.kj.yamagata-u.ac.jp

1 Faculty of Science, Yamagata University, 1-4-12

Kojirakawa-machi, Yamagata 990-8560, Japan

2 Graduate School of Life Sciences, Tohoku University, 2-1-1

Katahira, Aoba-ku, Sendai 980-8577, Japan need to obtain permission directly from the copyright holder. To view a copy of this licence, visit http://creativecommons.org/licenses/by/4.0/.

Publisher's Note Springer Nature remains neutral with regard to jurisdictional claims in published maps and institutional affiliations. 